[Chem. Pharm. Bull.

34( 1 ) $418-422$ (1986)

\title{
Angiotensin I Converting Enzymes in Rat Epididymis
}

\author{
Takamasa Yamaguchi, ${ }^{*}$ Hitoshi Toyoda, Masahiko Ikekita, \\ KAZUYUKi KizUKi and Hiroshi MORIYA
}

\author{
Department of Biochemistry, Faculty of Pharmaceutical Sciences, \\ Science University of Tokyo, 12 Ichigaya Funakawara-machi, \\ Shinjuku-ku, Tokyo 162, Japan
}

(Received June 25, 1981)

\begin{abstract}
When the homogenate of rat epididymis was fractionated by centrifugation, $55 \%$ of the total activity of angiotensin I converting enzyme (EC 3.4.15.1; ACE) was found in the $100000 \times g$ supernatant (soluble fraction) and about $40 \%$ in the $100000 \times g$ pellet (particulate fraction).

ACE from the soluble fraction was eluted as a single peak in TEAE-cellulose chromatography. This ACE was found to have smaller molecular size than rat testicular ACE by gel filtration through a Sephadex G-200 column.

On the other hand, in the case of ACE solubilized from the particulate fraction by treatment with sodium deoxycholate, two peaks of the activity (P-I and P-II fractions) were detected in TEAE-cellulose chromatography. ACE from the P-I fraction was found to have a smaller molecular size than rat testicular ACE, while ACE from the P-II fraction was found to have the same molecular size as rat pulmonary ACE when they were analyzed by gel filtration through the same column as mentioned above.

Thus, in the present investigation, different form of ACE were detected in rat epididymis. This is the first report of the presence of ACEs with molecular sizes smaller than that of rat testicular $\mathrm{ACE}$ (which had been reported to have lower molecular weight than rat pulmonary ACE) in soluble and particulate fractions of rat epididymis.
\end{abstract}

Keywords-angiotensin I converting enzyme; kininase II; renin-angiotensin system; kallikrein-kinin system; epididymis; testis; lung; rat

Angiotensin I converting enzyme (EC 3.4.15.1; kininase II, abbreviated as ACE) is a metallo-peptidase that activates angiotensin I into angiotensin II and inactivates kinins (bradykinin and kallidin) by its dipeptidyl carboxypeptidase activity. ${ }^{1)}$

Recently, ACEs were purified from rabbit ${ }^{2)}$ and rat $^{3,4)}$ testes and it was demonstrated that the molecular weights of testicular ACEs are smaller than those of the pulmonary enzymes in these animals. ${ }^{2-4)}$ In rat epididymis, Strittmatter and Snyder ${ }^{5)}$ observed the presence of ACE which had the same molecular weight as pulmonary ACE by using a monoclonal antibody that recognized only rat pulmonary ACE. They also observed that the content of this high molecular weight type (pulmonary type) ACE in rat epididymis was low, and most of the ACE in rat epididymis could not be recognized by the above-mentioned monoclonal antibody. ${ }^{5)}$ These observations suggest that most of the ACE in rat epididymis might be a different molecule from pulmonary ACE. Thus, in the present investigation, we attempted to characterize ACE in rat epididymis by chromatographic analyses.

\section{Experimental}

Materials $-N^{\alpha}$-Hippuryl-L-His-L-Leu-OH (HHL) and angiotensins I and II were purchased from the Peptide Institute, Inc. (Osaka, Japan). TEAE-cellulose was the product of Serva Finbiochemica GmbH \& Co. (Heidelberg, West Germany). Sephadex G-200, DEAE-Sephadex A-50 were from Pharmacia Fine Chemicals (Uppsala, Sweden). MK-422 was a kind gift from Nippon Merck Banyu Co., Ltd. (Tokyo, Japan). 
Rat pulmonary and testicular ACEs used as authentic ACEs in the gel filtration through a Sephadex G-200 column were purified according to the methods previously described. ${ }^{4}$ )

Determination of Enzyme Activity___Enzyme activity of ACE was measured using HHL as a substrate. Enzyme solution $(50 \mu \mathrm{l})$ was preincubated with $100 \mu \mathrm{l}$ of $0.125 \mathrm{M}$ borate-bicarbonate buffer, pH 8.3 , containing $1 \mathrm{M} \mathrm{NaCl}$ at $37^{\circ} \mathrm{C}$ for $5 \mathrm{~min}$, then $100 \mu \mathrm{l}$ of $12.5 \mathrm{~mm}$ HHL solution (in $0.125 \mathrm{M}$ borate-bicarbonate buffer, $\mathrm{pH} 8.3$, containing $1 \mathrm{M}$ $\mathrm{NaCl}$ ) was added to it. After incubation for $30 \mathrm{~min}$ at $37^{\circ} \mathrm{C}$, the enzyme reaction was terminated by the addition of $250 \mu \mathrm{l}$ of $1 \mathrm{~N} \mathrm{HCl}$. The amount of hippuric acid enzymatically liberated from HHL was determined according to the spectrophotometric method of Cushman and Cheung. ${ }^{6)}$ One unit (U) of the enzyme was defined as the amount of enzyme that can hydrolyzed $1 \mu \mathrm{mol} \mathrm{HHL}$ per minute at $37^{\circ} \mathrm{C}$.

Angiotensin I Converting Activity Assay-Angiotensin I converting activity was examined by the Magnus method using an isolated rat uterus. ${ }^{7)}$ Angiothensin I solution ( $760 \mathrm{pmol}$ in $0.7 \mathrm{ml}$ of $15 \mathrm{~mm}$ sodium phosphate buffer, $\mathrm{pH} 7.0$, containing $0.4 \mathrm{M} \mathrm{NaCl})$ was incubated with enzyme solution $\left(10 \mathrm{mU}\right.$ in $0.1 \mathrm{ml}$ of $10 \mathrm{mM}$ imidazole- $\mathrm{H}_{2} \mathrm{SO}_{4}$ buffer, $\mathrm{pH} 7.0$ ) for $20 \mathrm{~min}$ in the absence or in the presence of $1 \mathrm{mM} \mathrm{MK}-422$ at $37^{\circ} \mathrm{C}$. After that, $0.1 \mathrm{ml}$ of the reaction mixture was added to the organ bath $(10 \mathrm{ml})$ and the contractile activity of angiotensin II generated was recorded.

Preparations of Particulate and Soluble Fractions of Rat Epididymis-All procedures described below were carried out at $4^{\circ} \mathrm{C}$.

Wistar male rats (11 weeks old, 300-350 g) were sacrificed by exsanguination from the carotid artery. Epididymides were taken from eight animals in one experiment. The adipose tissue was removed, and the epididymides were chopped into small pieces with scissors. Then, 9 vol. of $50 \mathrm{~mm}$ Tris- $\mathrm{HCl}$ buffer, $\mathrm{pH} 7.4$, containing $0.25 \mathrm{M}$ sucrose (buffer A) was added. The mixture was homogenized in a Polytron PCU-2 (Kinematica, Switzerland) for $1 \mathrm{~min}$, and the homogenate was filtered through a nylon net. The filtrate was centrifuged for $15 \mathrm{~min}$ at $600 \times g$ and the supernatant (Sup I) and pellet (Plt I) were obtained. Sup I was recentrifuged for $15 \mathrm{~min}$ at $600 \times \mathrm{g}$, and the supernatant (Sup II) and pellet (PIt II) were obtained. On the other hand, Plt I was resuspended in $10 \mathrm{ml}$ of buffer A and was centrifuged for $15 \mathrm{~min}$ at $600 \times \mathrm{g}$ to give the supernatant (Sup III) and pellet (Plt III). Plt II and Plt III were combined and resuspended in $5 \mathrm{~mm}$ Tris $-\mathrm{HCl}$ buffer, $\mathrm{pH} 8.3$, containing $0.25 \mathrm{M}$ sucrose (buffer B). This suspension was stored at $4{ }^{\circ} \mathrm{C}$ as a particulate I fraction until usage for ACE assay. Sup II and Sup III were also combined and centrifuged for $1 \mathrm{~h}$ at $100000 \times \mathrm{g}$. The obtained pellet was resuspended in buffer $\mathrm{B}$ and stored at $4^{\circ} \mathrm{C}$ as a particulate II fraction. The obtained supernatant was also stored at $4{ }^{\circ} \mathrm{C}$ as a final supernatant fraction.

Enzyme activities of the particulate fractions were determined in the presence of sucrose (final concentration: $0.05 \mathrm{M})$ to avoid precipitation of the insoluble particles during the incubation periods. Therefore, dilutions of particulate fractions were carried out with buffer B. On the other hand, the enzyme activity of the final supernatant fraction was determined after dialysis against $5 \mathrm{~mm}$ Tris- $\mathrm{HCl}$ buffer, $\mathrm{pH} 8.3$, for $15 \mathrm{~h}$. We observed no difference between the enzyme activities of the final supernatant fraction determined in the presence and the absence of $0.05 \mathrm{M}$ sucrose in the assay mixture.

\section{Results}

Contents of HHL Hydrolyzing Activity in Soluble and Particulate Fractions of Rat Epididymis As shown in Table I, HHL hydrolyzing activities were found in both the soluble and particulate fractions of rat epididymis, i.e., about 55 and $42 \%$ of the activity were found in the final supernatant and particulate II fractions, respectively. Only about $1.3 \%$ of the total activity was found in particulate I fraction.

All these HHL hydrolyzing activities were completely inhibited by MK-422 (final concentration: $1 \mu \mathrm{M}$ ), a specific inhibitor of ACE. ${ }^{8)}$

TABLE I. Contents of HHL Hydrolyzing Activity of ACE in Soluble and Particulate Fractions of Rat Epididymis

\begin{tabular}{lcc}
\hline \hline Fraction & $\begin{array}{c}\text { Activity } \\
(\mathrm{U} / \mathrm{g} \text { tissue })^{a)}\end{array}$ & $\begin{array}{c}\text { Recovery } \\
(\%)\end{array}$ \\
\hline Homogenate & $11.20 \pm 1.17$ & 100 \\
Particulate I & $0.15 \pm 0.02$ & 1.3 \\
Particulate II & $4.70 \pm 0.40$ & 42.0 \\
Final supernatant & $6.16 \pm 0.65$ & 55.0 \\
\hline
\end{tabular}

a) Mean \pm S.D. of three experiments (eight animals were used in each experiment). 


\section{Chromatographic Analyses of ACEs in Soluble and Particulate Fractions of Rat Epididymis}

Figure 1 shows the result of TEAE-cellulose chromatography of the final supernatant fraction. A single peak of HHL hydrolyzing activity was eluted at the electric conductivity of $6.2 \mathrm{m \mho} / \mathrm{cm}$. Fractions No. 31-50 were pooled and concentrated for gel filtration. The same elution profile of enzyme activity as in Fig. 1 was observed when the final supernatant fraction was treated with a detergent such as sodium deoxycholate and subjected to TEAE-cellulose chromatography (chromatogram not shown).

Figure 2 shows the result of TEAE-cellulose chromatography of the solubilized materials obtained from particulate II fraction by treatment with sodium deoxycholate. In this case, two peaks of HHL hydrolyzing activity were detected at the electric conductivities of 7 and $11 \mathrm{~m} \mho / \mathrm{cm}$, respectively. The first peak (fractions No. 35-60) and the second peak (fractions No. 70-100) were separately pooled as P-I and P-II for further gel filtration.

The above three pooled fractions were separately gel filtered through a Sephadex G-200 column (Fig. 3). L and $\mathrm{T}$ in the figure show the elution positions of the purified rat pulmonary and testicular ACEs, respectively.

As shown in Fig. 3(A), when the pooled fraction in Fig. 1 was gel filtered, HHL hydrolyzing activity was detected at an elution position later than those of the purified rat pulmonary and testicular ACEs.

Figure 3(B) shows the elution profile when P-I fraction was gel filtered throuh the same column. As in the case of the final supernatant fraction (Fig. 3(A)), the elution position of HHL hydrolyzing activity was later than those of pulmonary and testicular ACEs.

Meanwhile, when P-II fraction was gel filtered through the same column, HHL hydrolyzing activity was detected at the same elution position as that of pulmonary ACE (Fig.

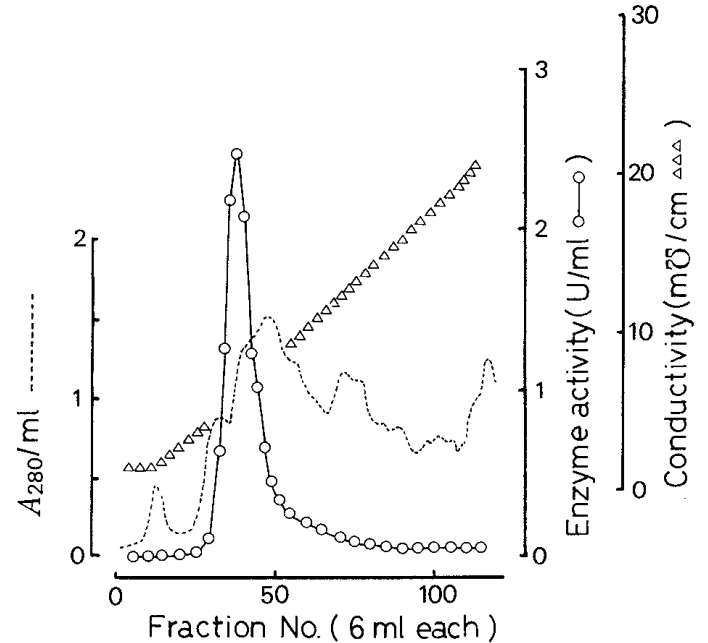

Fig. 1. TEAE-cellulose Chromatography of the Soluble Fraction of Rat Epididymis

The final supernatant fraction obtained from 24 animals was dialyzed twice against 81 of $25 \mathrm{~mm}$ Tris$\mathrm{HCl}$ buffer, $\mathrm{pH} 8.0$, for $12 \mathrm{~h}$. The dialysate $(185 \mathrm{U} /$ $270 \mathrm{ml}$ ) was applied to a TEAE-cellulose column $(2.5 \times 22 \mathrm{~cm})$ which had been equilibrated with the same buffer. The column was washed with 11 of the same buffer, then adsorbed materials were eluted with a linear gradient of $\mathrm{NaCl}(0$ to $0.25 \mathrm{M} \mathrm{NaCl}$ in $25 \mathrm{~mm}$ Tris- $\mathrm{HCl}$ buffer, $\mathrm{pH} 8.0$; total $900 \mathrm{ml}$ ).

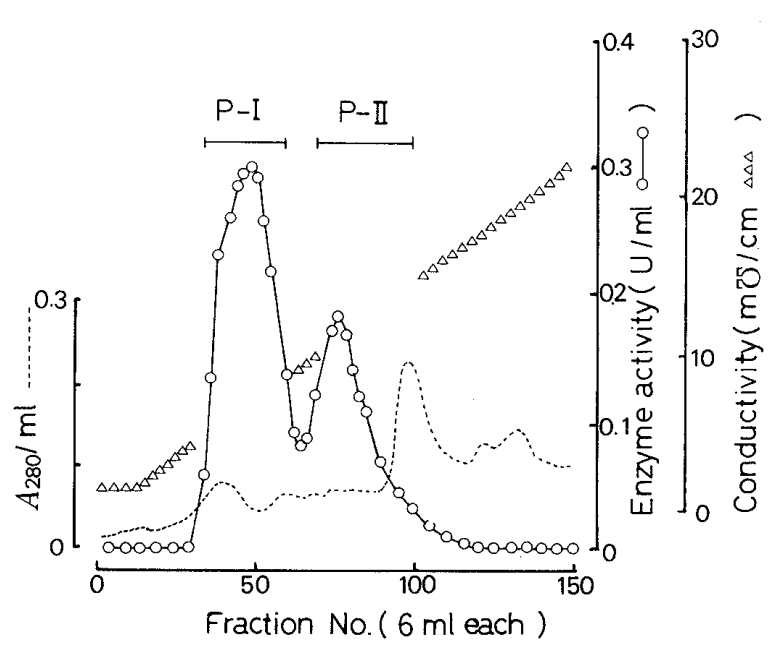

Fig. 2. TEAE-cellulose Chromatography of Materials Solubilized from Particulate II by Sodium Deoxycholate

Sodium deoxycholate was added to a suspension of particulate II fraction obtained from 24 animals $(130 \mathrm{U} / 160 \mathrm{ml})$ to make a final concentration of $0.25 \%$ $(\mathrm{w} / \mathrm{v})$. After being stirred for $3 \mathrm{~h}$ at $4{ }^{\circ} \mathrm{C}$, the suspension was centrifuged for $1 \mathrm{~h}$ at $100000 \times g$. The obtained supernatant was dialyzed twice against 81 of $25 \mathrm{~mm}$ Tris- $\mathrm{HCl}$ buffer, $\mathrm{pH} 8.0$ for $12 \mathrm{~h}$. The dialysate $(190 \mathrm{U} / 192 \mathrm{ml})$ was applied to a TEAE-cellulose column $(2.5 \times 22 \mathrm{~cm})$ which had been equilibrated with the same buffer. The column was washed with 11 of the same buffer, and adsorbed materials were eluted with a linear gradient of $\mathrm{NaCl}(0$ to $0.25 \mathrm{M} \mathrm{NaCl}$ in $25 \mathrm{~mm}$ Tris- $\mathrm{HCl}$ buffer, $\mathrm{pH} 8.0$; total $900 \mathrm{ml}$ ). 


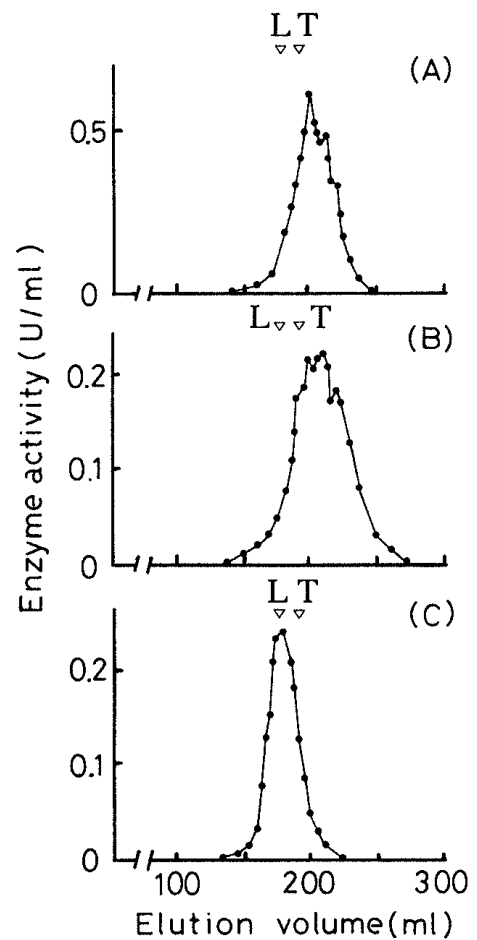

Fig. 3. Sephadex G-200 Gel Filtrations of ACEs Obtained from TEAE-cellulose Chromatographies

Three ACE preparations from TEAE-cellulose chromatographies (Fig. 1 and Fig. 2) were separately dialyzed for $12 \mathrm{~h}$ against $8 \mathrm{l}$ of $5 \mathrm{~mm}$ Tris- $\mathrm{HCl}$ buffer, $\mathrm{pH}$ 8.0. Each dialysate was applied to a DEAESephadex A-50 column $(5 \mathrm{ml})$ and adsorbed materials were eluted with $15 \mathrm{ml}$ of $25 \mathrm{~mm}$ Tris- $\mathrm{HCl}$ buffer, $\mathrm{pH}$ 8.0 , containing $0.2 \mathrm{M} \mathrm{NaCl}$. A portion $(5 \mathrm{ml})$ of the sample from the final supernatant fraction $(45.0 \mathrm{U})$ and $15 \mathrm{ml}$ of P-I (34.7 U) and P-II (12.7 U) were each further concentrated with a Minicon B-15 concentrator (Amicon, U.S.A.). Then, they were separately applied to a Sephadex G-200 column $(2.6 \times 65.5 \mathrm{~cm})$ which had been equilibrated with $25 \mathrm{~mm}$ Tris $-\mathrm{HCl}$ buffer, $\mathrm{pH} 8.0$, containing $0.1 \mathrm{M} \mathrm{NaCl}$. Gel filtration was carried out by reverse flow at the flow rate of $14.38 \mathrm{ml} / \mathrm{h}$. (A), (B) and (C) show the results of the pooled fraction in Fig. 1, and P-I and P-II in Fig. 2, respectively.

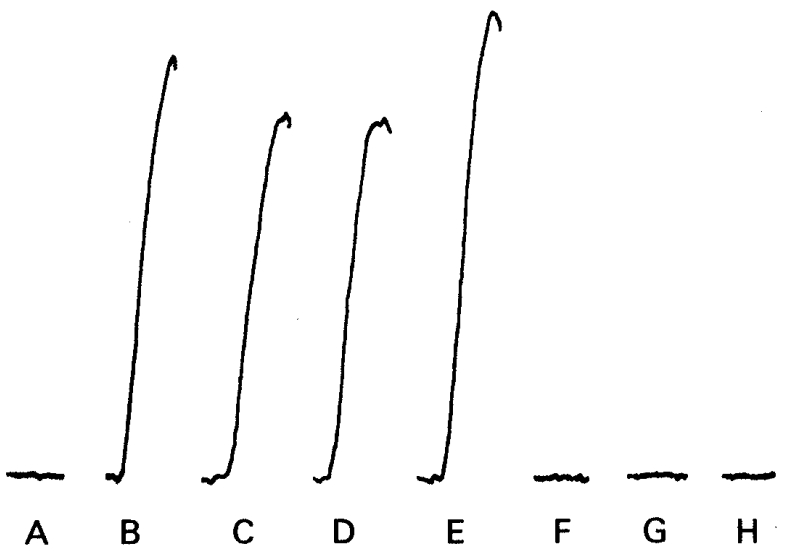

Fig. 4. Angiotensin I Converting Activities of the HHL Hydrolyzing Enzymes Obtained from Gel Filtrations of the Soluble, the P-I and P-II Fractions of Rat Epididymis

Fractions containing HHL hydrolyzing activities shown in Fig. 3(A), (B) and (C) were separately pooled and dialyzed against $10 \mathrm{~mm}$ imidazole- $\mathrm{H}_{2} \mathrm{SO}_{4}$ buffer, $\mathrm{pH}$ 7.0. Enzyme reactions were carried out according to the method described in Experimental.

A, control I: angiotensin I ( $95 \mathrm{pmol})$. B, angiotensin $\mathrm{I}+$ the enzyme in the soluble fraction. $\mathrm{C}$, angiotensin $\mathrm{I}+$ the enzyme in the P-I fraction. $\mathrm{D}$, angiotensin I t the enzyme in the P-II fraction. E, control II: angiotensin II $(95 \mathrm{pmol}) . \mathrm{F}, \mathrm{B}$ in the presence of $1 \mathrm{~mm}$ MK-422. G, C in the presence of $1 \mathrm{mM}$ MK-422. H, D in the presence of $1 \mathrm{~mm}$ MK- 422 .

3(C)).

Fractions containing HHL hydrolyzing activities shown in Fig. 3(A), (B) and (C) were separately pooled and the angiotensin I converting activity of each pooled fraction was examined by means of the Magnus assay. As shown in Fig. 4B, C and D, angiotensin I converting activity was observed in all the pooled fractions. All these angiotensin I converting activities shown in Fig. 4 were completely inhibited by $1 \mathrm{mM} \mathrm{MK}-422$ (F, G and H).

\section{Discussion}

In the present investigation, HHL hydrolyzing activity was detected in both soluble and particulate fractions of rat epididymis. The amount of the activity in the soluble fraction was slightly higher than that in the particulate fraction. This observation agrees with that of Jaiswal et al., ${ }^{9)}$ but is different from that of Strittmatter and Snyder, ${ }^{5)}$ who reported that the 
amount of HHL hydrolyzing activity in particulate fraction was slightly higher than that in soluble fraction.

We detected one HHL hydrolyzing enzyme in the soluble fraction and two HHL hydrolyzing enzymes in the particulate fraction by the chromatographic analyses. The pooled fractions of these three HHL hydrolyzing enzymes had angiotensin I coverting activities and these angiotensin I converting activities were completely inhibited by MK-422. Thus, we concluded that these HHL hydrolyzing enzymes were ACEs.

ACE which had the same molecular size as that of rat pulmonary ACE $\left(M_{\mathrm{r}}, 150\right.$ kilodaltons ${ }^{4)}$ ) was detected in the P-II fraction. This ACE component was thought to be identical with the pulmonary type ACE that had been detected in the particulate fraction of rat epididymis by Strittmatter and Snyder' by using monoclonal antibody against rat pulmonary ACE. Strittmatter and Snyder ${ }^{5)}$ also reported the presence of another form of ACE that could not be recognized by the monoclonal antibody in soluble and particulate fractions of rat epididymis. However, the molecular size of the non-pulmonary type ACE was not determined. We observed, in the soluble and the P-I fractions, different forms of ACE whose molecular sizes did not coincide with that of rat pulmonary ACE. It is especially noteworthy that these non-pulmonary type ACEs in our present investigation were not testicular type $\operatorname{ACE}\left(M_{\mathrm{r}}, 104\right.$ kilodaltons $\left.^{4}\right)$, i.e., both of them had smaller molecular sizes than testicular ACE. of ACE.

Acknowledgement We thank Nippon Merck Banyu Co., Ltd. for the kind gift of MK-422, a specific inhibitor

\section{References}

1) E. G. Erdös, "Bradykinin, Kallidin and Kallikrein," Handb. Exp. Pharm., Vol. XXV, ed. by E. G. Erdös, Springer-Verlag, Berlin, 1979, pp. 428-487.

2) H. A. El-Dorry, H. G. Bull, K. Iwata, N. A. Thornberry, E. H. Cordes and R. L. Soffer, J. Biol. Chem., 257, 14128 (1982).

3) P. A. Velletri, M. L. Billingsley and W. Lovenberg, Biochim. Biophys. Acta, 839, 71 (1985).

4) T. Yamaguchi, M. Sekine, M. Ikekita, K. Kizuki and H. Moriya, Yakugaku Zasshi, 105, 491 (1985).

5) S. M. Strittmatter and S. H. Snyder, Endocrinology, 115, 2332 (1984).

6) D. W. Cushman and H. S. Cheung, Biochem. Pharmacol., 20, 1637 (1971).

7) H. Moriya and K. Kizuki, "Kallikrein-Kinin," ed. by H. Moriya and K. Abe, Kodansha, Tokyo, 1982, pp. $210-211$.

8) A. A. Patchett, E. Harris, E. W. Tristram, M. J. Myvratt, M. T. Wu, D. Taub, E. R. Peterson, T. J. Ikeler, J. ten Broeke, L. G. Payne, D. L. Ondeyka, E. D. Thornsett, W. J. Greenlee, N. S. Lohr, R. D. Hoffsommer, H. Joshua, W. V. Ruyle, J. W. Rothrock, S. D. Aster, A. L. Maycock, F. M. Robinson, R. Hirschmann, C. S. Sweet, E. H. Ulm, D. M. Gross, T. C. Vassil and C. A. Stone, Nature, 288, 280 (1980).

9) A. Jaiswal, P. Joshi, M. V. Kumar, J. N. Panda and L. N. Singh, Andrologia, 16, 410 (1984). 